\title{
A Family with Hereditary High Serum Thyroxine-Binding Globulin
}

\author{
Makoto KOMATSU*, NaOShi HANAMURA*, \\ Tatsuyuki SEKI*, Mitsuo NARATA* and Takai KURODA** \\ *Department of Surgery, Okaya-enrei Hospital, Okaya 394, and **Department of Surgery, \\ Shinshu University School of Medicine, Matsumoto 390, Japan
}

\begin{abstract}
A family with hereditary high serum thyroxine-binding globulin was studied. All the subjects studied were clinically euthyroid without goiter. The propositus (female), her mother and sister had high TBG, total $\mathrm{T}_{4}$ and total $\mathrm{T}_{3}$ with normal free $\mathrm{T}_{4^{\prime}}$ free $\mathrm{T}_{3}$ and $\mathrm{TSH}$. Her father's thyroid function was within the normal range. Possible etiologic factors causing secondary hyper-TBG-nemia were ruled out in all the affected subjects. Isoelectric focusing demonstrated qualitatively normal microheterogeneity, ruling out possible TBG variations caused by liver diseases, estrogen therapy or pregnancy. Although the mechanism involved in the TBG increase awaits further investigation, it could be an abnormality in the gene controlling the synthesis of TBG.
\end{abstract}

Key words: Hereditary TBG increase, Isoelectric focusing.

(Endocrine Journal 41: 467-470, 1994)

A HEREDITARY increase in serum thyroxinebinding globulin (TBG) was first reported by Beierwaltes and Robbins in 1959 [1]. To our knowledge there have been 29 additional families with high TBG reported since then [2-20]. It is an extremely rare disease even at present in comparison with hereditary TBG deficiency. According to Refetoff [21], its incidence is $0.004 \%$ (1:25000), while that of TBG deficiency is reported to be $0.02 \%$ (1:5000). Recently, we examined a family with hereditary high TBG and also analyzed isoelectric focusing of TBG.

\section{Materials and Methods}

\section{Subjects}

Blood samples were obtained from 4 members

Received: November 16, 1993

Accepted: March 18, 1994

Correspondence to: Dr. Makoto KOMATSU, Department of Surgery, Fujimi-kogen Hospital, 11100 Ochiai, Fujimimachi, Suwa-gun, Nagano-ken 399-02, Japan including the propositus of this family with hereditary TBG increase. A healthy 33-year-old male was also analyzed as a normal control.

\section{Assay}

The concentration of TBG was determined by means of a highly sensitive RIA commercial kit ("RIA-gnost ${ }^{\circledR}$ TBG", Hoechst UK Ltd, Behring Diagnostics, Hoechst House, Salisbury Road, Hounslow, Middlesex, UK). Serum total $\mathrm{T}_{3}$, total $\mathrm{T}_{4}$, free $\mathrm{T}_{3}$, free $\mathrm{T}_{4}$ and TSH were measured with commercial kits.

\section{Isoelectric focusing}

$0.1 \mathrm{ml}$ of serum from patients or normal subject was incubated with $0.01 \mathrm{ml}(3900 \mathrm{Ci} / \mathrm{mmol}, 308$ $\mu \mathrm{Ci} / \mathrm{ml}$ ) of $\left[{ }^{125} \mathrm{I}\right]$-thyroxine (Amersham Japan, Tokyo, Japan) at $4^{\circ} \mathrm{C}$ and subjected to isoelectric focusing by means of the Pharmacia Phastsystem (Pharmacia LKB Biotechnology, Sweden). 


\section{Case Report}

A 6-year-old girl was referred to our hospital to evaluate thyroid function. The patient's mother suspected that the anterior neck of the patient had been swollen around September, 1990. The patient consulted a nearby physician in early March, 1991 and abnormalities were detected in a serum thyroid hormone test. The patient was referred to our hospital for precise examination on March 27, 1991. Her family history was not remarkable. She had never suffered from any particular disease. Her height was $123.5 \mathrm{~cm}$; body weight, $24 \mathrm{~kg}$; blood pressure, $120 / 60 \mathrm{mmHg}$; pulse rate, 93 per min, regular; body temperature, $36.8^{\circ} \mathrm{C}$. The thyroid gland was not enlarged. No abnormalities were noted in general hematology and blood biochemistry tests among laboratory test at the first examination. The results of endocrinological tests were as follows (Table 1): Serum $\mathrm{T}_{3}$ and $\mathrm{T}_{4}$ were high (204.9 $\mathrm{ng} / \mathrm{d} l$ and $16.22 \mu \mathrm{g} / \mathrm{d} l$, respectively), but TSH, free $\mathrm{T}_{3}$ and free $\mathrm{T}_{4}$ were normal $(3.15 \mu \mathrm{U} /$ $\mathrm{ml}, 3.10 \mathrm{pg} / \mathrm{ml}$ and $1.44 \mathrm{ng} / \mathrm{dl}$, respectively). Serum TBG was high $(55 \mu \mathrm{g} / \mathrm{ml})$. Serum estrone $\left(E_{1}\right)$ and estradiol $\left(\mathrm{E}_{2}\right)$ were normal $(5.0 \mathrm{pg} / \mathrm{ml}$ and 10.0 $\mathrm{pg} / \mathrm{ml}$, respectively). On ultrasonography of the thyroid, the size of the thyroid gland and internal echo level were within the normal range, and no thyroid nodules were observed. Since there were no possible causes of secondary hyper-TBG-nemia, hereditary high TBG was suspected and precise examinations were conducted including blood relatives of the patient. The family branches are shown in Fig. 1. The results of serum thyroid hormone tests of the patient's blood relatives are shown in Table 1. Serum TBG and $\mathrm{T}_{4}$ were high in the patient's mother and elder sister. Serum $T_{3}$ was also high in her elder sister. Serum TSH, free
$\mathrm{T}_{3}$ and free $\mathrm{T}_{4}$ were normal. Secondary factors such as hyperestrogenemia and hepatitis were all ruled out in the blood relatives including her mother whose serum TBG was only slightly high compared with those of the patient and her elder sister. Ultrasonography of the thyroid in each blood relative showed the size of the thyroid glands and internal echo level to be within the normal range, and no thyroid nodules were noted. The isoelectric focusing analysis of TBG in the patient and her blood relatives is shown in Fig. 2. No band shift was noted in comparison to the control.

\section{Discussion}

The majority of thyroid hormones are bound to thyroxine binding globulin (TBG), thyroxine binding prealbumin (TBPA) and albumin in human serum. Since hyper-TBG-nemia exhibits a high level

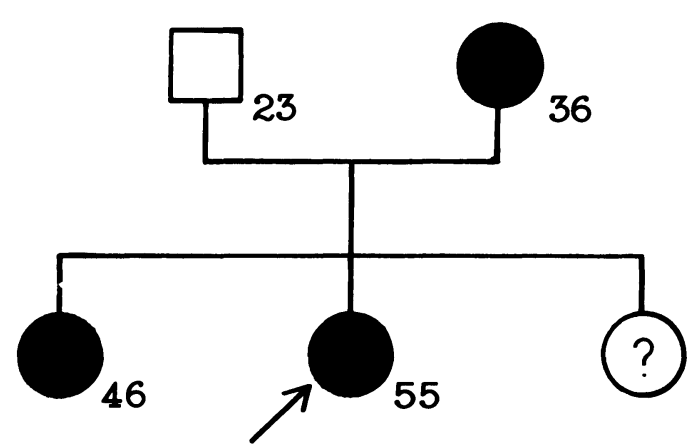

Fig. 1. Pedigree of family with high TBG. Numbers under each symbol are concentrations of TBG in micrograms per milliliter of serum. Open box, unaffected male; hatched circles, affected females; ? mark in open circle, female not studied in detail; arrow, propositus.

Table 1. Serum thyroid hormone tests of the propositus, her blood relatives and normal control

\begin{tabular}{lccccccc}
\hline Sample & $\begin{array}{c}\text { Age } \\
\text { (y.o.) }\end{array}$ & $\begin{array}{c}\mathrm{T}_{3} \\
{[\mathrm{ng} / \mathrm{d} l]}\end{array}$ & $\begin{array}{c}\mathrm{T}_{4} \\
{[\mu \mathrm{g} / \mathrm{d} l]}\end{array}$ & $\begin{array}{c}\mathrm{TSH} \\
{[\mu \mathrm{U} / \mathrm{m} l]}\end{array}$ & $\begin{array}{c}\text { Free } \mathrm{T}_{3} \\
{[\mathrm{pg} / \mathrm{m} l]}\end{array}$ & $\begin{array}{c}\text { Free }_{4} \\
{[\mathrm{ng} / \mathrm{d} l]}\end{array}$ & $\begin{array}{c}\mathrm{TBG} \\
{[\mu \mathrm{g} / \mathrm{m} l]}\end{array}$ \\
\hline 1 Father & 42 & 117.3 & 10.13 & 0.51 & 3.01 & 1.67 & 23 \\
2 Mother & 36 & 109.1 & 11.53 & 1.53 & 2.36 & 1.12 & 36 \\
3 Elder sister & 10 & 205.4 & 14.22 & 2.18 & 3.25 & 1.55 & 46 \\
4 Propositus (female) & 6 & 204.9 & 16.22 & 3.15 & 3.10 & 1.44 & 55 \\
$\quad$ Younger sister & 4 & \multicolumn{7}{c}{ not studied in detail } \\
5 Normal control (male) & 33 & 78.7 & 7.27 & 2.56 & 2.54 & 1.07 & 13 \\
\hline Normal range & & $(70-200)$ & $(5.4-11.3)$ & $(0.5-5.5)$ & $(2.62-3.78)$ & $(0.70-1.90)$ & $(14-28)$ \\
\hline
\end{tabular}



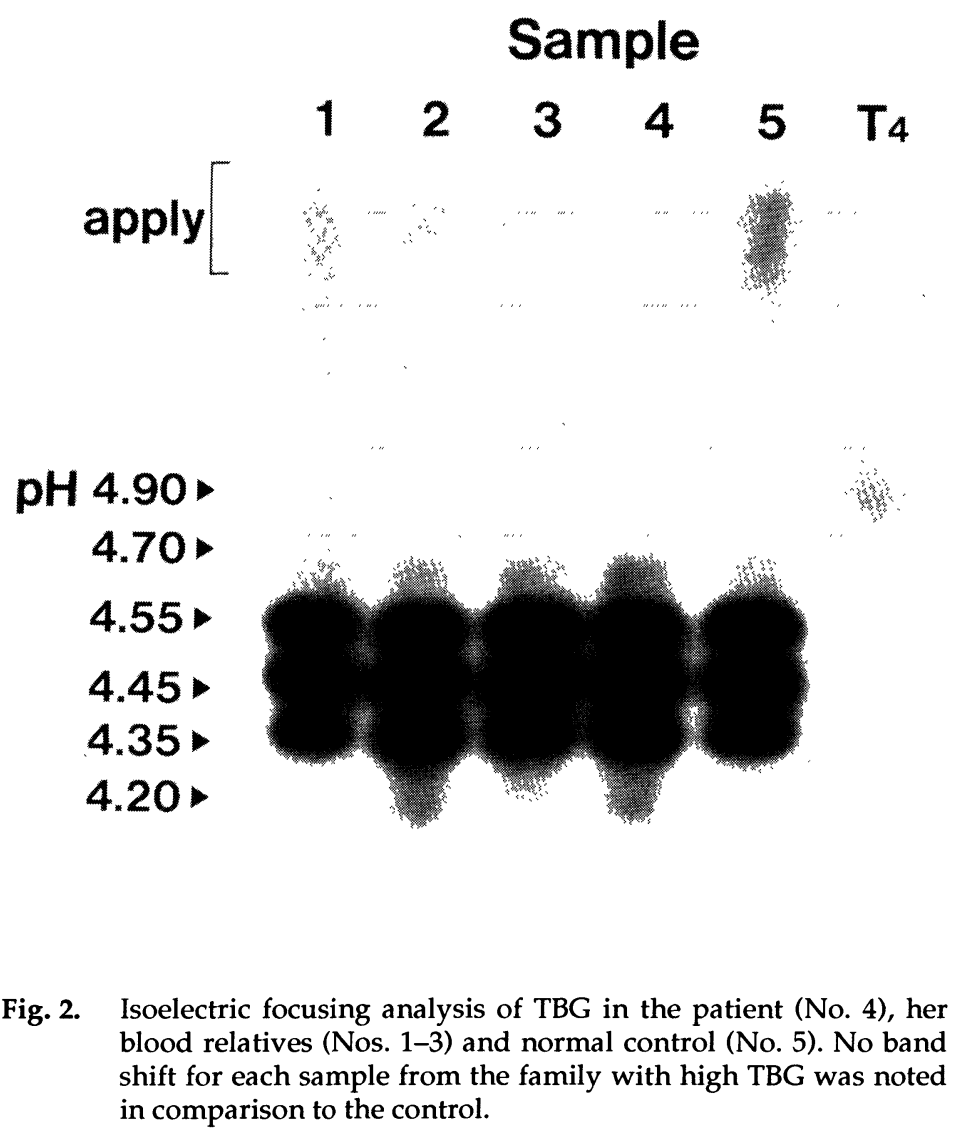

of serum $\mathrm{T}_{4}$ in spite of normal thyroid function, it is occasionally misdiagnosed as hyperthyroidism and treated accordingly [11]. Moreover, there have been reports of hyper-TBG-nemia accompanying Basedow's disease [13, 14]. The interpretation of thyroid functions therefore calls for caution in such cases.

Possible causes of the high level of TBG include 1) pregnancy, 2) infancy, 3) administration of estrogen and oral contraceptives, 4) acute intermittent porphyria, 5) acute and chronic active hepatitis, 6) heredity, 7) heroin addiction and 8) administration of perphenazine. In the current case, it was impossible that estrogen was involved, and there were no symptoms of porphyria. Hepatic functions were normal, and the patient was not using heroin or perphenazine. Moreover, since hyper-TBGnemia without secondary factors was noted in the patient's mother and elder sister, hereditary increase in TBG was diagnosed.

The pattern of inheritance of a hereditary increase in TBG has been considered to be dominant inheritance on the $X$ gene $[3,5,7,15,16,17,21]$. In the family we studied, the condition in the first generation occurred in a female, and there were no males with this condition even in the second generation. Thus, we could not obtain evidence supporting the hypothesis of inheritance on the $X$ gene which suggests that it is never inherited by male children from fathers. However, our findings are considered not to contradict the hypothesis of inheritance on the $X$ gene.

Hereditary TBG deficiency used to be regarded as an abnormality in the quantity. As a result of physicochemical examinations of TBG molecules involving such factors as $\mathrm{T}_{4}$-binding affinity, electrophoresis on the isoelectric point, and thermal stability in the 1980s, it has been proved to involve abnormalities in quality in addition to those in quantity [22]. On the other hand, no qualitative abnormalities have been suggested in previous reports on increased TBG $[16,17,20]$. No qualitative abnormalities were noted in this family either, as a result of isoelectric focusing analysis. Refetoff [21] and his colleagues have ruled out gene duplication by restriction fragment length polymorphism, and, 
in their opinion point mutations at sites regulating gene expression are the most probable postulate for the mechanism leading to hereditary TBG increase.

A newly-detected family with hereditary TBG increase has been reported in this article. The mechanism of the onset of this condition remains unknown, and further investigations are awaited.

\section{Acknowledgements}

The authors thank Dr. Yutaka Nishii and Dr. Akihiro Sakurai, Department of Geriatrics, Endocrinology and Metabolism, Shinshu University School of Medicine, Matsumoto, Japan, for their invaluable advice, and Miss Naomi Otsuka for her secretary assistance.

\section{References}

1. Beierwaltes $W H$, Robbins J (1959) Familial increase in thyroxine-binding sites in serum alpha globulin. J Clin Invest 38: 1683-1688.

2. Florsheim WH, Dowling JT, Meister L, Bodfish RE (1962) Familial elevation of serum thyroxine-binding capacity. J Clin Endocrinol Metab 22: 735-740.

3. Jones LE, Seal US (1967) X-chromosome linked inheritance of thyroxine-binding globulin. J Clin Endocrinol Metab 27: 1521-1528.

4. Siesbaek-Nielsen K, Hansen JM, Hoppe E (1969) Familial elevation of serum thyroxine-binding globulin activity. Acta Endocrinol (Copenh) 60: 130136.

5. Fialkow PJ, Giblett ER, Musa B (1970) Increased serum thyroxine-binding globulin capacity: Inheritance and linkage relationships. J Clin Endocrinol Metab 30: 66-70.

6. Shishiba Y, Shimizu T, Yoshimura S, Shizume K (1970) A pedigree with hereditary increase in thyroxine binding globulin. Folia Endocrinol Japon 46: 1002-1004 (In Japanese).

7. Shane SR, Seal US, Jones JE (1971) X-chromosome linked inheritance of elevated thyroxine-binding globulin in association with goiter. J Clin Endocrinol Metab 32: 587-594.

8. Refetoff S, Robin NI, Alper CA (1972) Study of four new kindreds with inherited thyroxine-binding globulin abnormalities. J Clin Invest 51: 848-867.

9. Hodgson SF, Wahner HW (1972) Hereditary increased thyroxine-binding-globulin capacity. Mayo Clin Proc 47: 720-724.

10. Thomson JA, Meredith EM, Baird SG, Mcanish WR, Hutchison JH (1972) Raised free thyroxine values in patients with familial elevation of thyroxinebinding globulin. Q J Med 161: 49-56.

11. Buchanam BD, Hagen GA (1979) Elevated thyroxine-binding globulin with X-chromosome linked inheritance. Clin Endocrinol (Oxf) 11: 665-669.

12. Tajima $H$, Umetsu $M$, Shimizu $T$, Nakamori $Y$, Shishiba $Y$ (1979) A pedigree with hereditary increase in thyroxine binding globulin: second report in Japan. Folia Endocrinol Japon 55: 313 (Abstract)
(In Japanese).

13. Kimura $H$, Inoue $K$, Oki $T$, Hasegawa $M$, Kuriya $Y$, Kojima T, Miyamoto M, Ban Y, Iino S (1979) A case with familial increase in thyroxine binding globulin associated with Basedow's disease. Folia Endocrinol Japon 55: 1178 (Abstract) (In Japanese).

14. Yabu Y, Amino N, Nakatani K, Ichihara K, Azukizawa M, Miyai K (1980) Graves' disease associated with elevated serum thyroxine-binding globulin concentrations. J Clin Endocrinol Metab 51: 325-329.

15. Penhaligon J, Wellby ML (1982) Elevated serum thyroxine-binding globulin by X-chromosome transmission. Acta Endocrinol 99: 393-396.

16. Sigurdsson GA, Arnason G, Gugmundsson Th V, Kjeld M, Franzson L, Sigurdsson G (1984) Familial elevation of serum thyroxine binding globulin in Icelandic family. Acta Endocrinol 107: 352-356.

17. Frank K, Gartner R, Raue F, Zigler R (1986) Inherited thyroxine-binding globulin excess. Study in a kindred. Exp Clin Endocrinol 88: 237-241.

18. Yamada I, Okano K, Yajima M, Sasagawa K, Ohira J, Nayori C, Ko K, Fujibayashi S, Kato T, Someya K (1986) A case with familial elevation in thyroxine binding globulin. Hormone to Rinsho 34: 208-210 (Supplement) (In Japanese).

19. Kobayashi T, Tsukakoshi H, Imai N, Kobayashi S, Takemura Y (1988) A pedigree with familial elevation of serum thyroxine binding globulin. Sogo Rinsho 37: 765-768 (In Japanese).

20. Ain KB, Refetoff S (1988) Relationship of oligosaccharide modification to the cause of serum thyroxine-binding globulin excess. J Clin Endocrinol Metab 66: 1037-1043.

21. Refetoff S (1989) Inherited thyroxine-binding globulin abnormalities in man. Endocrine Reviews 10: 275-293.

22. Murata Y, Takamatsu J, Refetoff S (1986) Inherited abnormality of thyroxine-binding globulin with no demonstrable thyroxine-binding affinity and high serum levels of denatured thyroxine binding globulin. N Engl J Med 314: 694-699. 